\title{
Significance of bacteria in urea dynamics in coastal surface waters
}

\author{
B. C. Cho ${ }^{1, *}$, M. G. Park ${ }^{1}$, J. H. Shim ${ }^{1}$, F. Azam $^{2}$ \\ ${ }^{1}$ Department of Oceanography, Seoul National University, 151-742, Seoul, Republic of Korea \\ ${ }^{2}$ Scripps Institution of Oceanography, University of California at San Diego, La Jolla, California 92093-0202, USA
}

\begin{abstract}
Bacterial urea production and decomposition were studied in samples from coastal waters in the Southern California Bight (the Bight), USA, and an estuarine system of the Mankyung and Dongjin rivers (MD estuary) in Korea. Bacterial urea production ranged from undetectable to $139 \mathrm{nM}$ $\mathrm{d}^{-1}$, and the mean value of bacterial urea production $\left(58 \mathrm{nM} \mathrm{d}^{-1}, \mathrm{n}=6\right.$ ) was equivalent to $35-91 \%$ of the estimated phytoplankton $\mathrm{N}$ demand in the Bight. The rates of bacterial production of urea were 2 orders of magnitude higher than the bacterial urea decomposition rates. Consequently, bacteria were consistently net producers of urea in the euphotic zone. The concentration-dependence of urea decomposition showed the presence of a high affinity but low capacity system $\left(K_{1}+S_{n}: 26\right.$ to $33 \mathrm{nM}, V_{\max }: 3$ to $11 \mathrm{nM} \mathrm{d}^{-1}$ ). The low $K_{\mathrm{m}}$ values indicate that in typical seawater samples, which have $>100 \mathrm{nM}$ urea, the bacterial ureolysis system is always near-saturated. The significance of bacteria as urea producers should be incorporated into models of nitrogen regeneration in surface waters.
\end{abstract}

KEY WORDS: Bacteria $\cdot$ Urea production - Urea decomposition - Coastal waters

\section{INTRODUCTION}

Urea is one of the major nitrogen $(\mathrm{N})$ sources for primary production in the ocean and a large contributor to the oceanic 'regenerated production' (Eppley \& Peterson 1979, Harrison et al. 1985). In order to understand the regulation of $\mathrm{N}$ regeneration, it is important to find out which organisms are responsible for urea production in the euphotic zone and what mechanisms regulate urea production. The general perception has been that urea is mainly produced by metazod. For instance, McCarthy \& Whitledge (1972) concluded, based on extrapolation of laboratory measurements to field conditions, that most of the urea demand of phytoplankton could be explained by urea production by zooplankton and fish. In a field study in the central North Pacific gyre, Eppley et al. (1973) concluded that urea excretion by zooplankton could explain 40 to $110 \%$ of urea utilization by phytoplankton. However, recently Harrison et al. (1985) reported that dominant macrozooplankton species in the eastern Canadian

·E-mail: bccho@plaza.snu.ac.kr
Arctic supplied only ca $3 \%$ of the urea-N requirements of the phytoplankton. The possible contribution of microorganisms to the observed urea production rates was not examined in these studies.

More recent studies indicate that microorganisms may be quite important in urea production. Price et al. (1985) measured urea production rates in the Strait of Georgia (Vancouver, Canada) in intact seawater samples. They found that $\mathrm{N}$ regeneration processes generated urea at rates similar to (frontal region) or 2 - to 5 -fold larger than (stratified waters) ammonium regeneration rates. They proposed a model which included (dissolved organic nitrogen) DON $\rightarrow$ urea as an important pathway of $\mathrm{N}$ flux but they did not identify the organisms responsible for mediating this regenerative flux. Hansell \& Goering (1989) and Slawyk et al. (1990) used isotope dilution methods to measure in situ urea production rates. They found that planktonic assemblages $<333 \mu$ m (Hansell \& Goering 1989) or <200 um (Slawyk et al. 1990) regenerated urea rapidly enough to replenish the urea pool in less than $1 \mathrm{~d}$. While these studies implied that bacteria were, in part, responsible for urea production, they did not quantify the contribution of bacteria to urea production. Bacterial metabolism of purines, pyrimidines, argi- 
nine and hypoxanthine is known to result in urea production (Turley 1985, Mobley \& Hausinger 1989). It is therefore possible that the utilization of these DON components by natural assemblages of bacteria in seawater produces urea at rates which are significant in total urea regeneration.

The goal of this study was to test whether bacteria in the planktonic microbial assemblages are significant producers of urea in surface waters.

\section{MATERIALS AND METHODS}

Study area and sample collection. Surface seawater samples were collected with a sterile 1 l polycarbonate (Nalgene ${ }^{\otimes}$ ) flask at the end of the Scripps pier in California, USA $\left(32^{\circ} 53^{\prime} \mathrm{N}, 117^{\circ} 15^{\prime} \mathrm{W}\right)$ and in the estuarine system of the Mankyung and Dongjin rivers (MD estuary), Korea (Fig. 1). The MD estuary is a shallow (mostly $<10 \mathrm{~m}$ ) and tidally mixed estuary (for further description see Cho \& Shim 1992). The salinity at the sampling stations ranges from 18 to $32 \%$. Additional samples were collected at 4 stations during cruises in the Southern California Bight (the Bight) in October
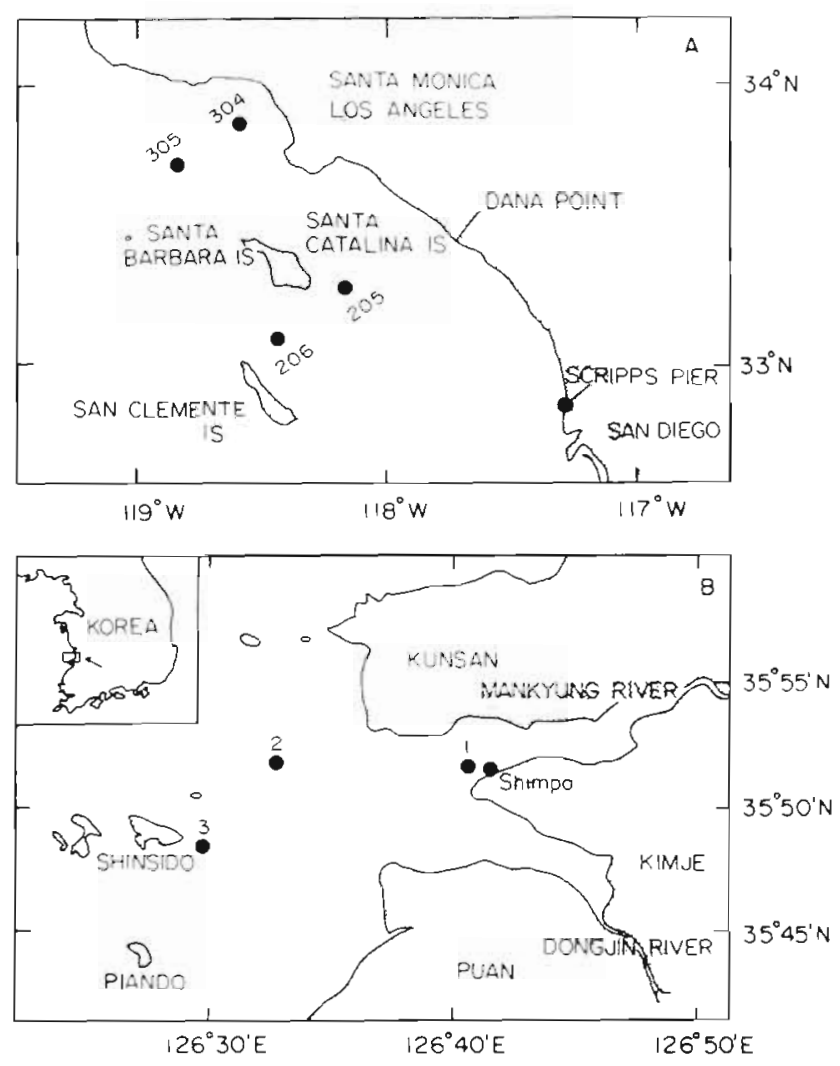

Fig. 1. Sampling stations in (A) the Southern. California Bight, USA and (B) an estuarine system of the Mankyung and Dongjin rivers in Korea
1985, September 1988, and February 1992. Subsurface samples were taken with a Niskin bottle.

Urea production. In order to measure bacterial production of urea dissociated from urea uptake by phytoplankton, the seawater was fractionated through 0.6 or $0.8 \mu \mathrm{m}$ Nuclepore filters (Bight samples) or GF/C filters with nominal pore-size of $1.2 \mu \mathrm{m}$ (MD estuary). The reason for using different filters for size-fractionation was that the same pore-size filters were not available on all field trips. These filters permit a major fraction of bacteria to pass but retain most of the phytoplankton. One bottle or duplicate bottles of the filtrates (volume of 1 to $2 \mathrm{l}$ ) were incubated at in situ temperature in the dark for 10 to $24 \mathrm{~h}$, and the abundance of bacteria and urea concentration were measured periodically. Filtrates added with neutral buffered formalin (final conc. of $1 \%$ ) served as blanks for the MD estuary samples. In one experiment (Scripps pier sample, December 1985), we tested whether bacteria rather than non-bacterial contaminants (protozoa and picophytoplanktonj were responsible for urea production. We inoculated $0.2 \mu \mathrm{m}$ filtered seawater with the natural assemblages of bacteria in $0.6 \mu \mathrm{m}$ filtrate $(2 \% \mathrm{v} / \mathrm{v})$ and incubated (seawater culture, SWC $i$ Ammerman et al. 1984) the SWC in the dark at in situ temperature. Bacterial abundance and urea concentration were determined periodically. In 5 experiments, the time-course of urea accumulation was monitored (Fig 2) while in the other 5 samples only the starting and the end-point concentrations of urea were determined (see Table 1). Production rates of urea for the size-fractionated samples were calculated using linear regression for the whole incubation period (Fig. 2A, B) or for the initial $(6 \mathrm{~h})$ linear part of the incubation (Fig, 2C, D). The production rate of urea for the SWC was calculated for the incubation period from 18 to $53 \mathrm{~h}$ (Fig. 2E). Rates of bacterial cell production were estimated in all experiments over the same time intervals as those of urea production.

Urea decomposition. Measurements of urea decomposition activity were followed with added ${ }^{14} \mathrm{C}$-urea. essentially by the method of Remsen et al. (1974). In most experiments, $50 \mathrm{ml}$ of seawater $(0.6,0.8$ or $1.2 \mu \mathrm{m}$ and $183 \mu \mathrm{m}$ size-fractionated samples or whole seawater) was amended with $0.2 \mu \mathrm{m}$ filter-sterilized ${ }^{14} \mathrm{C}$-urea ( 54 to $58 \mathrm{mCi} \mathrm{mmol}^{-1}, \mathrm{NEN}$ ) to attain 0.25 to $0.62 \mu \mathrm{Ci}$ per sample. The resulting concentration of added urea was 86.2 to $252.5 \mathrm{nM}$ (except in experiments to study concentration-dependence of urea decomposition; below). For some samples this addition could not be regarded as true tracer, but it did not substantially increase the rates as the bacterial urease systems were near saturation at the natural urea concentrations (see 'Discussion'). Samples were incubated under whitefluorescence light, in situ light, or in the dark. One bottle was fixed with neutral buffered formalin (final conc. 

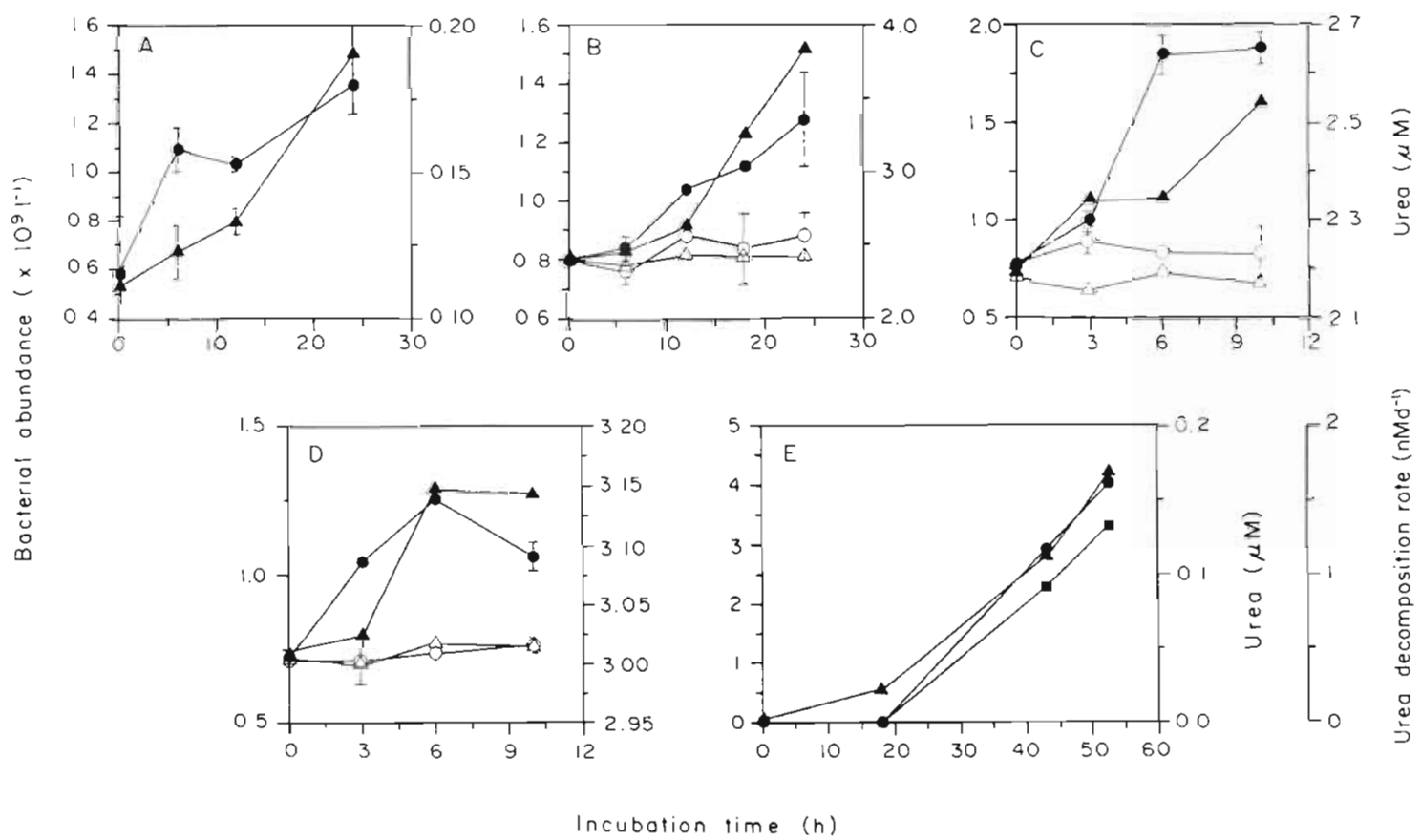

Fig. 2. (A) Changes of mean values of bacterial abundance ( $\bullet$ ) and urea ( $\bullet$ ) in duplicate bottles of $0.6 \mu \mathrm{m}$ filtrates from the Scripps pier (January 1989). (B-D) Those in single bottle of GF/C filtrates from the Mankyung and Dongjin rivers estuary ((B) November 1992; (C, D) June 1993). ( $\Delta$, o) Formalin-killed blanks. (E) Changes of bacterial abundance $(\mathbf{A})$, urea $(\bullet)$, and urea decomposition activity (-) in seawater culture (December 1985). All samples were from the surface. Error bars are $1 \mathrm{SD}$

of $1 \%$ ) and served as a control. After incubation with ${ }^{14} \mathrm{C}$-urea for 1 or $2 \mathrm{~h}, 1 \mathrm{ml}$ of $2 \mathrm{~N} \mathrm{H}_{2} \mathrm{SO}_{4}$ was added to the samples placed in a gas-tight container. Liberated ${ }^{14} \mathrm{CO}_{2}$ was collected in $0.2 \mathrm{ml}$ of phenethylamine and radioassayed by liquid scintillation spectrometry using the external standard ratio method. Urea decomposition rates were calculated as: $(f / t) \times($ in situ urea concentration), where $f=$ fraction of the trace ${ }^{14} \mathrm{C}$ converted to ${ }^{14} \mathrm{CO}_{2}$ and $t=$ duration of incubation. All measurements were done at least in duplicates. The coefficient of variation among replicates was usually $<7 \%$.

The concentration-dependence of urea decomposition was determined in $1.0 \mathrm{\mu m}$ pore-size Nuclepore filtrates (bacterial fraction) for 2 samples taken in the Bight, one from $150 \mathrm{~m}$ at Stn 206 and other at the end of the Scripps pier. Addition of mixtures of ${ }^{14} \mathrm{C}$-urea and unlabeled urea was made to achieve final concentrations of added urea from 17 to $1600 \mathrm{nM}$ (Scripps pier) or 9 to $4300 \mathrm{nM}$ (Stn 206). The initial rates of decomposition of the added urea to ${ }^{14} \mathrm{CO}_{2}$ were determined in 30 min incubations following the procedure described above. A modified Eadie-Hoftsee plot (Azam \& Hodson 1981) was used to determine $V_{\max }$ and $K_{\mathrm{t}}+S_{\mathrm{n}}$ (where $S_{\mathrm{n}}$ is the natural concentration of urea).

Other analyses. Urea was measured by the urease method of McCarthy (1970) on the day of experiment for the Bight samples between December 1985 and
1989. Bight samples from 1992 and samples from the MD estuary were frozen and brought to the laboratory to measure urea concentration by the method of Price \& Harrison (1987). We did not observe any significant changes in urea concentration for the MD estuary samples analyzed within a week (not shown). Ammonium was measured by the method of Strickland \& Parsons (1972) or Grasshoff et al. (1983). Bacteria were enumerated by epifluorescence microscopy of acridine orange stained samples (Hobbie et al. 1977).

\section{RESULTS}

\section{Urea production}

The rate of accumulation of urea in the filtrates varied from undetectable to $139 \mathrm{nM} \mathrm{d}^{-1}$ in the Bight and from 264 to $1176 \mathrm{nM} \mathrm{d}^{-1}$ in the MD estuary (Table 1) The increase in urea roughly paralleled the increase in bacterial abundance. Formalin killed blanks showed no changes in urea concentration (Fig. 2B, C, D). The seawater culture (SWC) showed an increase in urea concentration in parallel to the increase in bacterial abundance (Fig. 2E). The rate of urea production of $112 \mathrm{nM} \mathrm{d}^{-1}$ was linear for the incubation period of 18 to $53 \mathrm{~h}$. Per-cell urea production rates ranged from 40 to 1348 amol cell $^{-1} \mathrm{~d}^{-1}$ (Table 1). 
Table 1. Initial urea concentration, initial bacterial abundance in filtrates $(<0.8 \mu m$ Nuclepore or GF/C filtrates), production rates of urea and bacteria in seawater culture and filtrates, and per-cell urea production rates. Samples were from Stn 305 and the Scripps pier in the Southern California Bight (Bight), USA and from Stn Shimpo in the estuarine system of the Mankyung and Dongjin (MD estuary) rivers, southwest coast of Korea

\begin{tabular}{|c|c|c|c|c|c|c|c|}
\hline Location & Date & $\begin{array}{l}\text { Depth } \\
(\mathrm{m})\end{array}$ & $\begin{array}{l}\text { Urea } \\
\text { (nM) }\end{array}$ & $\begin{array}{l}\text { Bacterial } \\
\text { abundance } \\
\left(\times 10^{9} \mathrm{l}^{-1}\right)\end{array}$ & $\begin{array}{l}\text { Produc } \\
\text { Urea } \\
\left\{n M \mathrm{~d}^{-1}\right)\end{array}$ & $\begin{array}{l}\text { rates of: } \\
\text { Bacteria } \\
\text { (cells } \mathrm{I}^{-1} \mathrm{~d}^{-1} \text { ) }\end{array}$ & $\begin{array}{l}\text { Per-cell urea } \\
\text { production rates } \\
\text { (amol cell }{ }^{-1} \mathrm{~d}^{-1} \text { ) }\end{array}$ \\
\hline \multicolumn{8}{|l|}{ Bight } \\
\hline \multirow[t]{3}{*}{ Stn 305} & Sep 1988 & 20 & $166 \pm 27$ & 1.3 & 38 & - & - \\
\hline & & 40 & $179 \pm 12$ & - & 139 & - & - \\
\hline & Feb 1992 & 10,30 & $--^{a}$ & - & $n d^{b}$ & - & - \\
\hline \multirow[t]{2}{*}{ Scripps pier } & $\operatorname{Jan} 1989$ & 0 & $115 \pm 5$ & 0.5 & 56 & $9.6 \times 10^{8}$ & 58 \\
\hline & Dec $1985^{\circ}$ & 0 & $n d^{b}$ & 1.1 & 112 & $28.2 \times 10^{8}$ & 40 \\
\hline \multirow[t]{4}{*}{ MD estuary } & Nov 1992 & 0 & $2400 \pm 150$ & 0.8 & 984 & $7.3 \times 10^{8}$ & 1348 \\
\hline & Feb 1993 & 0 & $697 \pm 231$ & 0.3 & 264 & $6.4 \times 10^{b}$ & 413 \\
\hline & Jun 1993 & 0 & $2210 \pm 13$ & 0.8 & 1176 & $13.9 \times 10^{8}$ & 846 \\
\hline & & 0 & $3005 \pm 70$ & 0.7 & 528 & $21.1 \times 10^{8}$ & 250 \\
\hline
\end{tabular}

\section{Urea decomposition}

Urea decomposition rate in the actively growing SWC was neglible $\left(0.3 \mathrm{amol}\right.$ cell $\mathrm{d}^{-1} \mathrm{~d}^{-1}$ or $1.1 \mathrm{nM} \mathrm{d}^{-1}$; Fig. 2E) in comparison with the urea accumulation rate of $112 \mathrm{nM} \mathrm{d}^{-1}$ (above).

The bacterial fractions $(<0.8 \mu \mathrm{m})$ in the Bight samples showed low urea decomposition rates in compari-

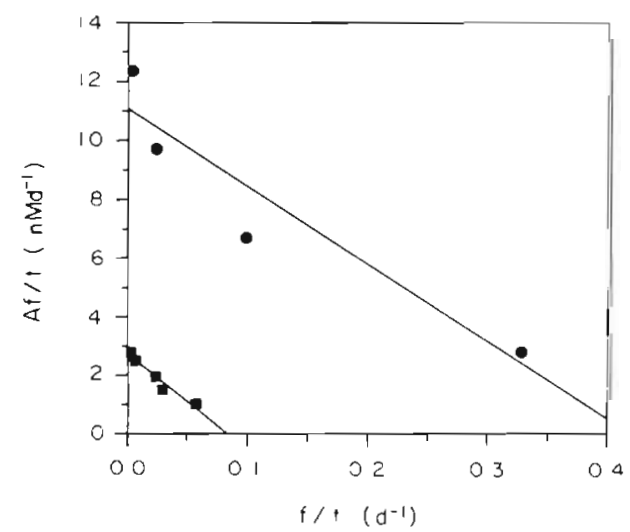

Fig. 3. Modified Eadie-Hoftsee plots of urea decomposition activity data for samples from the $<1.0 \mu \mathrm{m}$ fraction from the

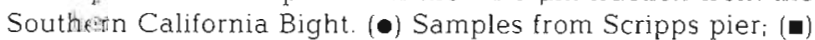
samples from $150 \mathrm{~m}$ at $\operatorname{Sin} 206$. f/t: fraction of total urea pool decomposed per day. Slope $=-\left(K_{\mathrm{t}}+S_{n}\right) ; y$-intercept $=V_{\max }$

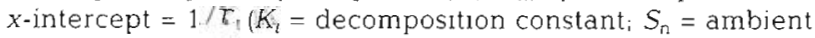
concentration; $V_{\max }=$ maximum decomposition rate $T_{1}=$ turnover time at the ambient concentration). Regression equations: Scripps pier, $y^{\prime}=10.8-25.9 f / t_{i} \operatorname{Stn} 206, y^{\prime}=2.8-$ $33.3 \mathrm{f} / t_{i}$ where $y^{\prime}$ is multiplication of added urea concentration $(A)$ and $f / t$ son with the $<183 \mu \mathrm{m}$ filtrable fraction $(0$ to $22 \%$; Table 2). Bacterial fractions (GF/C filtrates) in the MD estuary samples also showed low urea decomposition rates in comparison with the whole seawater $(0$ to $10 \%$; Table 2) with one exceptionally high value of $64 \%$. The per-bacterium rates of urea decomposition calculated for the bacterial fraction (on the assumption that all urea decomposition in these filtrates was due to bacteria) ranged from 0 to $8 \mathrm{amol} \mathrm{cell}{ }^{-1} \mathrm{~d}^{-1}$ (Table 2).

The kinetic data of urea decomposition by natural assemblages of marine bacteria in $1.0 \mu \mathrm{m}$ filtrate yielded a linear fit on a modified Eadie-Hoftsee plot (Fig. 3). The sample off Scripps pier had a $K_{\mathrm{t}}+S_{\mathrm{n}}$ of $26 \mathrm{nM}$ and $\mathrm{a} V_{\max }$ of $11 \mathrm{nM} \mathrm{d}^{-1}$. The corresponding values for $\operatorname{Stn} 206$ were $33 \mathrm{nM}$ and $3 \mathrm{nM} \mathrm{d}^{-1}$ Per-cell $V_{\max }$ was 13 amol cell ${ }^{-1} \mathrm{~d}^{-1}$ for the sample from Stn 206. Bacterial abundance data was not determined for the Scripps pier sample. If we assume it was $10^{9} \mathrm{I}^{-1}$ in the bacterial fraction (Cho 1988), then the per-cell $V_{\text {max }}$ for the pier sample was 11 amol cell ${ }^{-1} \mathrm{~d}^{-1}$. Thus, the percell $V_{\max }$ values for the 2 samples, one from the euphotic and the other from the aphotic zone, would be similar.

\section{DISCUSSION}

\section{Urea production by bacteria}

The urea production rates which we ascribed to bacteria were obtained for operationally defined 'bacterial size-fractions' $(<0.6,<0.8 \mu \mathrm{m}$ and GF/C filtrate). The interpretation of the SWC experiment is the least 
Table 2. Bacterial abundance in $<0.8 \mu \mathrm{m}$ filtrate, in situ urea concentration, urea decomposition in $<0.8 \mu \mathrm{m}$ filtrates and $<183 \mu \mathrm{m}$ filtrates, ratio of urea decomposition rates in $<0.8 \mu \mathrm{m}$ filtrates to $<183 \mu \mathrm{m}$ filtrates, and per-cell urea decomposition rate in the euphotic zone of the Southern California Bight (Bight). In the MD estuary, GF/C filtrates and whole seawater were used for the measurements of urea decomposition

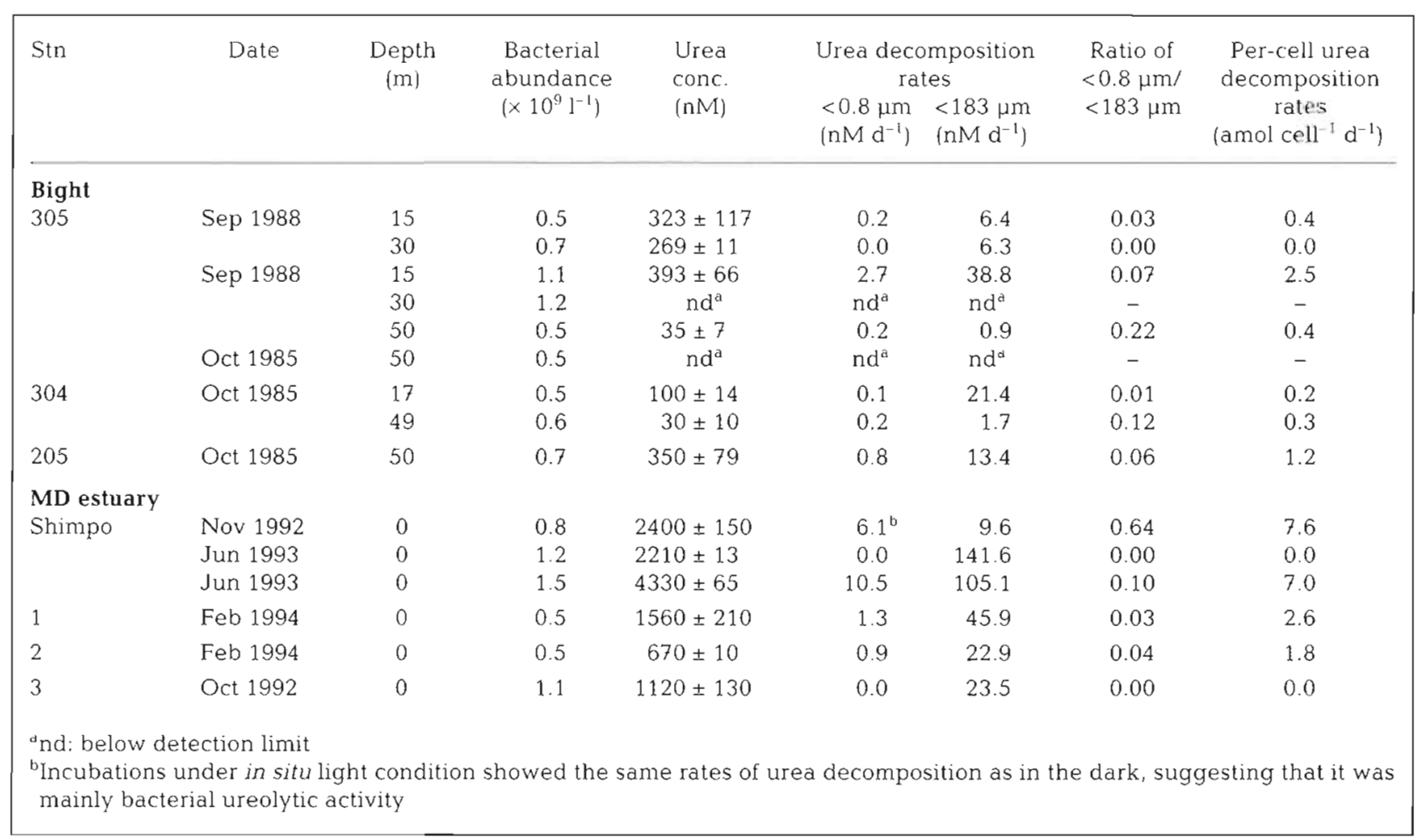

ambiguous. The inoculum consisted of $2 \%(\mathrm{v} / \mathrm{v})$ of $0.6 \mu \mathrm{m}$ Nuclepore filtrate and was therefore expected to exclude phytoplankton and protozoa and include bacteria (and unavoidably, viruses as well). In examining the samples for bacterial counts ( 2 to $5 \mathrm{ml}$ samples; 10 to 20 microscope fields at $1250 \times$ ) we did not observe any phytoplankton or protozoa. The seawater culture generated urea in parallel with the accumulation of bacteria beyond the $18 \mathrm{~h}$ time point (Fig. 2E). Abiotic urea production was considered negligible since it was undetectable between 0 and $18 \mathrm{~h}$ (Fig. 2E). We therefore conclude that the urea accumulation rate $(112 \mathrm{nM}$ $\mathrm{d}^{-1}$ for the period between $18 \mathrm{~h}$ and $53 \mathrm{~h}$ ) was largely due to bacteria.

The urea concentrations in our study (below detection limit to $393 \mathrm{nM}$ in the Bight, 670 to $4330 \mathrm{nM}$ in the MD estuary) were within the range of previous studies in the Bight (McCarthy 1970. McCarthy \& Kamykowski 1972, Cho \& Azam 1995) and MD estuary (Shim et al. 1994). Our data of urea concentrations were also comparable to the studies done in other coastal areas (Steinmann 1976, Turley 1985) and estuaries (Remsen et al. 1972, Webb \& Haas 1976).

The urea measurements in the 'bacterial size-fractions' (Nuclepore and GF/C filtrates) were made to obtain conservative estimates of the in situ rates of urea production due to bacteria. The estimates are conservative because at our sampling sites generally $\sim 10 \%$ of bacteria are retained by the filters. There was no obvious contamination of the filtrates with phytoplankton and protozoa as judged on the basis of samples examined for bacterial counts. We cannot rule out that some protozoa passed the filters we used for sizefractionation, but their populations remained too low to be detected in the samples we examined.

The mean rate of bacterial urea production in the Bight was $58 \pm 58 \mathrm{nM} \mathrm{d}^{-1}$ (mean $\pm \mathrm{SD}, \mathrm{n}=6$, equivalent to $\left.1.6 \mu \mathrm{g} \mathrm{N}^{-1} \mathrm{~d}^{-1}\right)$ while higher rates $\left(738 \pm 417 \mathrm{nM} \mathrm{d}^{-1}\right.$, mean $\pm S D, n=4$ ) were found in the MD estuary. Since primary production data and historical data on urea demand in phytoplankton is available for the Bight, we can use the Bight data to evaluate if the urea production rates contributed significantly to the phytoplankton $\mathrm{N}$ demand and phytoplankton urea- $\mathrm{N}$ demand. The phytoplankton $N$ demand in the Bight was estimated to be 1.8 to $4.6 \mu \mathrm{g} \mathrm{N}^{-1} \mathrm{~d}^{-1}$ as follows: during our study the primary production was 883 to $2315 \mathrm{nM} \mathrm{C} \mathrm{d}^{-1}$ or 126 to $331 \mathrm{nM} \mathrm{N} \mathrm{d} \mathrm{N}^{-1}$ (assuming that $\mathrm{C} / \mathrm{N}$ was 7 and the euphotic depth $50 \mathrm{~m}$ ). Thus, our mean rate of urea production was equivalent to $35-91 \%$ of the estimated 
phytoplankton N demand. NicCarthy (1972) found that $28 \%$ of the primary production in the Bight could be supported by urea. For the calculation we used the mean value of the urea production rates. Individual values are highly variable (above) and they would result in bacterial urea production being equivalent to $0 \%$ to well over $100 \%$ of the phytoplankton $\mathrm{N}$ demand. Thus, it seems that bacterial production of urea at times could contribute significantly to the urea dynamics, and supply a large fraction of the urea demand of the phytoplankton. Literature data show that urea and ammonium may be equally important as $N$ source for phytoplankton. Except in high nitrate waters, where urea contributes only $4 \%$ of total $N$ uptake by phytoplankton (Kokkinakis \& Wheeler 1987), urea usually comprises from 19 to $80 \%$ of total $\mathrm{N}$ uptake by phytoplankton in marine environments (Kristiansen 1983, Harrison et al. 1985, Sahlsten 1987. Probyn 1988, Sahlsten et al. 1988, Hansell \& Goering 1990, Glibert et al. 1991). Thus, bacterial production of urea could be a significant source of urea- $\mathrm{N}$ to phytoplankton in marine environments.

There are no previous measurements in our study areas to which we can compare our rates of bacterial production of urea. Production rates in the Bight are considerably lower than those for total seawater in the Strait of Georgia (648 to $1128 \mathrm{nM} \mathrm{d}^{-1}$; Price et al. 1985), in Mikawa Bay (624 nM d ${ }^{-1}$; Mitamura \& Saijo 1975), for the $<333 \mu \mathrm{m}$ size fraction of seawater in the Bering Sea (600 to $1176 \mathrm{nM} \mathrm{d}^{-1}$; Hansell \& Goering 1989) and for the $<200 \mu \mathrm{m}$ filtrable fraction off the Galapagos Islands (1100 $\mathrm{nM} \mathrm{d}^{-1}$; Slawyk et al. 1990). Bacterial urea production rates in the MD estuary (528 to $1176 \mathrm{nM} \mathrm{d}^{-1}$ ), however, were similar to the values reported above. These regional differences could be due to differences in factors such as dissolved organic nitrogen and/or bacterial activity.

Per-cell urea production rates were in the range of 40 to 1348 amol cell $^{-1} \mathrm{~d}^{-1}$ (1.1. to $37.7 \mathrm{fg} \mathrm{N}$ cell ${ }^{-1} \mathrm{~d}^{-1}$; Table 1). Per-cell urea production rates were much faster in the MD estuary than in the Bight (Table 1). Bacterial abundance and bacterial production were not related to per-cell urea production rates in this study, Per-cell urea production rates were in most cases close to or larger than the daily bacterial $N$ demand for growth, assuming a bacterial $N$ content of 3.4 to $11.6 \mathrm{fg}_{\mathrm{cell}}^{-1}$ for the range of small natural marine bacteria $\left(0.036 \mu^{3}\right.$; Simon \& Azam 1989) and large growing bacteria in seawater culture $\left(0.25 \mathrm{~km}^{3}\right.$; Ammerman et al. 1984). These results indicate that bacteria would excrete excess $N$ in an organic form such as urea, consistent with recent views that urea seems to be a major organic $\mathrm{N}$ compound released during bacterial growth (Jørgensen et al. 1993, Kroer et al. 1994).

\section{Urea decomposition by bacteria}

The characteristics of bacterial urea hydrolysis (Fig. 3) indicated the presence of a high affinity $\left(K_{1}+S_{n}\right.$ values of 26 and $33 \mathrm{nM}$ ) but low capacity system. Even if we treat the $K_{\mathrm{t}}+S_{\mathrm{n}}$ values as upper limits of $K_{\mathrm{m}}$, the values are much lower than the concentrations of urea in typical seawater samples. If the $K_{\mathrm{m}}$ values for 2 samples are applicable to the other samples then the urea hydrolysis should be close to $V_{\max }$. Only in 1 sample (MD estuary, June 1993), however, was urea decomposition rate in the bacterial fraction close to $V_{\max }$ of $11 \mathrm{nM} \mathrm{d}^{-1}$ (Table 2). Bacterial ureolytic activity in marine surface waters might not be fully expressed (see below)

The rates of urea decomposition in the SWC experiment were low $\left(0.9\right.$ and $1.3 \mathrm{nM} \mathrm{d}^{-1}$ at 42 and $53 \mathrm{~h}$ time points, respectively; Fig. 2E) compared to the corresponding rates of urea production (112 $\left.\mathrm{nM} \mathrm{d} \mathrm{d}^{-1}\right)$. Thus, the bacterial assemblages in the SWC were net producers of urea. Bacterial fractions $(<0.8 \mu \mathrm{m}$ Nuclepore filtrates) of a number of samples taken at stations in the Bight also showed very low rates of urea decomposition, ranging from zero to $3 \mathrm{nM} \mathrm{d} \mathrm{d}^{-1}$. By comparing this range of urea decomposition rates with rates of urea production in the Bight $\left(58 \pm 58 \mathrm{nM} \mathrm{d}^{-1}\right.$, mean $\left.\pm \mathrm{SD}\right)$ we conclude that the predominant role of the bacteria was to produce rather than decompose urea. The eutrophic MD estuary (chlorophyll $a:>1$ to $<20 \mu \mathrm{g} \mathrm{l}^{-1}$; $\mathrm{NH}_{4}{ }^{+}$: undetectable to $47 \mu \mathrm{M}$; Shim et al. 1994) showed higher urea decomposition rates $\left(0\right.$ to $10.5 \mathrm{nM} \mathrm{d} \mathrm{d}^{-1}$; Table 2). However, since the urea production rate was proportionately high (Table 1), the decomposition rate was only 0 to $4 \%$ of the production rate. Further, in 2 samples (November 1992 and June 1993; Tables 1 \& 2) in which both measurements of bacterial production and decomposition of urea were made, urea production rates were over 2 orders of magnitude higher than the bacterial urea decomposition. Thus, the conclusion that bacteria are net producers of urea appears to be valid for the examined mesotrophic and eutrophic environments.

Earlier studies have also found that planktonic bacterial assemblages play only a trivial role in urea decomposition (Remsen et al. 1974, Turley 1985). Good correlations between chlorophyll and urea decomposition, results of size-fractionation experiments similar to ours, and the fact that there is no energetic advantage for bacteria in using urea as an $\mathrm{N}$ source led Turley (1985) to conclude that 'bacteria rather ignore urea' in surface seawater samples. Although the relationship between chlorophyll a and urea decomposition was not studied here, our data are consistent with Turley (1985). Bacterial fractions (0.8 $\mu \mathrm{m}$ filtrates in the Bight and $\mathrm{GF} / \mathrm{C}$ filtrates in the MD estuary) usually showed 
$<12 \%$ of total activity. In one exceptional case, in the MD estuary, $64 \%$ of the total urea decomposition activity was in the GF/C filtrate. Dark and light incubations showed no differences in activity, indicating that most of the activity might have been due to bacteria. Our results on per-cell urea decomposition by bacteria (Table 2) also support the conclusion that bacterial decomposition of urea is generally insignificant in surface waters: in the Bight samples, if $\mathrm{N}$ generated by urea decomposition (mean of 0.6 amol cell-1 $\mathrm{d}^{-1}$ ) was assumed to be utilized as the sole source of $\mathrm{N}$ for bacterial growth of $5.6 \mathrm{fg} \mathrm{N} \mathrm{Nell}^{-1}$ (Lee \& Fuhrman 1987), it would support mean bacterial doubling times of $357 \mathrm{~d}$, which are 2 orders of magnitude longer than the observed doubling times of bacteria in the coastal waters of the Bight (on the order of 1 to $4 \mathrm{~d}$; Cho \& Azam 1988). In the MD estuary the bacterial doubling time which could be supported by urea decomposition (mean of 3.2 amol cell ${ }^{-1} \mathrm{~d}^{-1}$ ) was $63.1 \mathrm{~d}$ whereas the actual bacterial doubling time was $<1.1 \mathrm{~d}$ (Fig. 2B, C, D). In SWC it was shown that the per-cell urea hydrolysis rate could vary broadly and reach values as high as 54 amol cell ${ }^{-1} \mathrm{~d}^{-1}$ (Cho 1988). It appears, therefore, that per-cell rates of ureolysis are subject to large variations and that bacterial hydrolysis of urea could at times contribute significantly to bacterial $\mathrm{N}$ demand.

In conclusion, bacteria appear to be net producers of urea in the euphotic zone of the coastal and estuarine environments studied here. Bacterial urea production could satisfy a significant fraction of the phytoplankton $N$ demand. While urea decomposition by bacteria was generally insignificant relative to the bacterial $\mathrm{N}$ demand, it could be significant in $\mathrm{N}$-limited conditions. Our results here and in an earlier study of the mesopelagic environment (Cho \& Azam 1995) suggest that the role of bacteria in urea dynamics should be incorporated into models of oceanic $\mathrm{N}$ cycle.

Acknowledgements. We thank Dr G. Herndl for help in the field and laboratory experiments. We thank 3 anonymous reviewers for their constructive comments. The present studjes were supported by NSF grants (F.A.) and by the Basic Science Research Institute program, Ministry of Education, 1995. Project No. BSRI-95-5409 (B.C.C. and J.H.S.).

\section{LITERATURE CITED}

Ammerman JW, Fuhrman JA, Hagström A, Azam F (1984) Bacterioplankton growth in seawater. I. Growth kinetics and cellular characteristics in seawater cultures. Mar Ecol Prog Ser 18:31-39

Azam F, Hodson RE (1981) Multiphasic kinetics for D-glucose uptake by assemblages of natural marine bacteria. Mar Ecol Prog Ser 6:213-222

Cho BC (1988) Significance of bacteria in biogeochemical fluxes in the pelagic ocean. PhD thesis, University of California, San Diego

Cho BC, Azam. F (1988) Major role of bacteria in biogeochem. ical fluxes in the ocean's interior. Nature 332:441-443

Cho BC, Azam F (1995) Urea decomposition by bacteria in the Southern California Bight and its implications for the mesopelagic nitrogen cycle. Mar Ecol Prog Ser 122:21-26

Cho BC, Shim JH (1992) Significance of estuarine mixing in distribution of bacterial abundance and production in the estuarine system of the Mankyung River and Dongjin River, Korea. J Oceanol Soc Korea 27:154-163

Eppley RW, Peterson BJ (1979) Particulate organic matter flux and planktonic new production in the deep ocean. Nature 282:677-680

Eppley RW, Renger E, Venrick E, Mullin MM (1973) A study of plankton dynamics and nutrient cycling in the central gyre of the North Pacific Ocean. Limnol Oceanogr 18 $534-551$

Glibert PM, Garside C, Fuhrman JA, Roman MR (1991) Timedependent coupling of inorganic and organic nitrogen uptake and regeneration in the plume of the Chesapeake Bay estuary and its regulation by large heterotrophs. Limnol Oceanogr 36:895-909

Grasshoff K, Eberhardt M, Kremling K (1983) Methods of seawater analysis. Verlag Chemie, Weinheim

Hansell DA, Goering JJ (1989) A method for estimating uptake and production rates for urea in seawater using $\left[{ }^{14} \mathrm{C}\right.$ lurea and $\left[{ }^{15} \mathrm{~N}\right]$ urea. Can J Fish Aquat Sci 46:198-202

Hansell DA, Goering JJ (1990) Pelagic nitrogen flux in the northern Bering Sea. Cont Shelf Res 10:501-509

Harrison WG, Head EJD, Conover RJ, Longhurst AR, Sameoto DD (1985) The distribution and metabolism of urea in the eastern Canadian Arctic. Deep Sea Res 32 $23-42$

Hobbie JE, Daley RJ, Jasper S (1977) Use of Nuclepore filters for counting bacteria by epifluorescence microscopy. Appl Environ Microbiol 33:1225-1228

Jorgensen NOG, Kroer N, Coffin RB, Yang XH, Lee C (1993) Dissolved free amino acids, combined amino acids, and DNA as sources of carbon and nitrogen to marine bacteria. Mar Ecol Prog Ser 98:135-148

Kokkinakis SA, Wheeler PA (1987) Nitrogen uptake and phytoplankton growth in coastal upwelling regions. Limnol Oceanogr 32:1112-1123

Kristiansen S (1983) Urea as a nitrogen source for the phytoplankton in the Oslofjord. Mar Biol 74:17-24

Kroer N, Jørgensen NOG, Coffin RB (1994) Utilization of dissolved nitrogen by heterotrophic bacterioplankton: a comparison of three ecosystems. Appl Environ Microbiol 60 $4116-4123$

Lee S, Fuhrman JA (1987) Relationships between biovolume and biomass of naturally derived marine bacterioplankton. Appl Environ Microbiol 53:1298-1303

McCarthy JJ (1970) A urease method for urea in seawater. Limnol Oceanogr 15:309-313

McCarthy JJ (1972) The uptake of urea by natural populations of marine phytoplankton. Limnol Oceanogr 17:738-748

McCarthy JJ, Kamykowski D (1972) Urea and other nitrogenous nutrients in La Jolla Bay during February, March, and April 1970. Fish Bull US 70:1261-1274

McCarthy JJ, Whitledge TE (1972) Nitrogen excretion by anchovy (Engraulis mordax and E. ringens) and jack mackerel (Trachurus symmetricus). Fish Bull US 70: 395-401

Mitamura O, Saijo Y (1975) Decomposition of urea associated with photosynthesis of phytoplankton in coastal waters. Mar Biol 30:67-72

Mobley HLT, Hausinger RP (1989) Microbial ureases: significance, regulation, and molecular characterization. Microbiol Rev 53:85-108 
Price NM, Cochlan WP, Harrison PJ (1985) Time course of uptake of inorgane and organic nutrogen by phytoplankton in the Strait of Georgla: comparison of frontal and stratified communities. Mar Ecol Prog Ser 27:39-53

Price NM. Harrison PJ (1987) A comparison of methods for the measurement of dissolved urea concentration in seawater Mar Biol 92:307-319

Probyn TA (1988) Nitrogen utilization by phytoplankton in the Namibran upwelling region during an austral spring. Deep Sea Res 35:1387-1404

Remsen CC, Carpenter EJ, Schroeder BW (1972) Competition for urea among estuarine microorganisms. Ecology 53 : $921-926$

Remsen CC, Carpenter EJ, Schroeder BW (1974) The role of urea in marine microbial ecology. In: Colwell RR, Morita RY (eds) Effects of the ocean environment on microbial activities. University Park Press, Baltimore, p 286-304

Sahlsten E (1987) Nitrogenous nutrition in the euphotic zone of the Central North Pacific Gyre. Mar Biol 96:433-439

Sahlsten E, Sorensson F. Pelterson K (1988) Planktonic nitrogen uptake in the south-eastern Kattegat. J Exp Mar Biol Ecol 121:227-246

Shim JH, Cho BC, Park MG (1994) Distributions of urea and

This article was submitted to the editor urea decomposition rates in an estuarme system of Mankyung and Dongjin Rivers, Korea. J Korean Soc Oceanogr 29:402-413 (in Korean)

Simon M, Azam F (1989) Protem content and protein synthesis rates of planktonic marine bacteria. Mar Ecol Prog Ser 51:201-213

Slawyk G, Raimbault P, L'Helguen S (1990) Recovery of urea nitrogen from seawater for measurements of ${ }^{15} \mathrm{~N}$ abundance in urea regeneration studies using the isotope-dilution approach. Mar Chem 30:343-362

Steinmann J (1976) Untersuchungen über den bakteriellen Abbau von Harnstoff und Harnsäure in der westlichen Ostsee. Botanica Mar 19:47-58

Strickland JDH, Parsons TR (1972) A practical handbook of seawater analysis, 2nd edn. Bull Fish Res Bd Can 167

Turley CM (1985) Biological studies in the vicinity of a shallow-sea tidal mixing front. IV. Seasonal and temporal distribution of urea and its uptake by phytoplankton. Phil Trans R Soc Lond Ser B 310:471-500

Webb KL, Haas LW (1976) The significance of urea for phytoplankton nutrition in the York River, Virginia. In: Wiley $M$ (ed) Estuarine processes. Academic Press, New York, p $90-102$

Manuscript first received: June 27, 1995

Revised version accepted: April 24, 1996 